Article

\title{
Effect of Heat Treatment on Microstructure and Hardness of Grade 91 Steel
}

\author{
Triratna Shrestha ${ }^{1}$, Sultan F. Alsagabi ${ }^{1}$, Indrajit Charit ${ }^{1}$, Gabriel P. Potirniche ${ }^{2}$ and \\ Michael V. Glazoff ${ }^{3, *}$
}

1 Department of Chemical and Materials Engineering, University of Idaho, Moscow, ID 83844-3024, USA; E-Mails: triratna.shrestha@gmail.com (T.S.); ssagabi@kacst.edu.sa (S.F.A.); icharit@uidaho.edu (I.C.)

2 Department of Mechanical Engineering, University of Idaho, Moscow, ID 83844-0902, USA; E-Mail: gabrielp@uidaho.edu

3 Energy Systems Integration, Idaho National Laboratory, Idaho Falls, ID 83415-3710, USA

* Author to whom correspondence should be addressed; E-Mail: michael.glazoff@inl.gov; Tel.: +1-208-526-8937.

Academic Editor: Hugo F. Lopez

Received: 4 December 2014 / Accepted: 12 January 2015 / Published: 21 January 2015

\begin{abstract}
Grade 91 steel (modified 9Cr-1Mo steel) is considered a prospective material for the Next Generation Nuclear Power Plant for application in reactor pressure vessels at temperatures of up to $650{ }^{\circ} \mathrm{C}$. In this study, heat treatment of Grade 91 steel was performed by normalizing and tempering the steel at various temperatures for different periods of time. Optical microscopy, scanning and transmission electron microscopy in conjunction with microhardness profiles and calorimetric plots were used to understand the microstructural evolution including precipitate structures and were correlated with mechanical behavior of the steel. Thermo-Calc ${ }^{\mathrm{TM}}$ calculations were used to support the experimental work. Furthermore, carbon isopleth and temperature dependencies of the volume fraction of different precipitates were constructed.
\end{abstract}

Keywords: modified 9Cr-1Mo steel; Grade 91 steel; heat treatment; microstructure; differential scanning calorimetry; Thermo-Calc ${ }^{\mathrm{TM}}$; precipitates 


\section{Introduction}

The Next Generation Nuclear Plant (NGNP) is expected to address the growing energy demand by producing electricity and, at the same time, mitigate greenhouse gas emissions by co-producing hydrogen from the process heat. The Very High Temperature Reactor (VHTR) is a Gen-IV reactor system at the heart of the NGNP. VHTRs are designed to operate at temperatures much higher than those of currently operating reactors. Moreover, they are designed for longer service periods (60 years or more) compared to the current operating reactors [1]. The operating temperature of the reactor pressure vessel (RPV) in VHTR can vary between 300 and $650{ }^{\circ} \mathrm{C}$. Furthermore, the RPVs will be more than double the size of a typical RPV as found in a Light Water Reactor (LWR) [2].

The modified 9Cr-1Mo steel (Grade 91) is a material of choice in fossil-fuel-fired power plants with increased efficiency, service life, and reduction in emissions of $\mathrm{CO}_{2}, \mathrm{NO}_{x}$, and $\mathrm{SO}_{2}$. The efficiency of fossil-fired power strongly depends on the temperature and pressure of steam. One percent increase in net efficiency reduced the emission of $\mathrm{CO}_{2}, \mathrm{NO}_{x}, \mathrm{SO}_{2}$, and particulates by 2.4 metric ton, 2000 ton, 2000 ton, and 500 ton, respectively, while also reducing fuel costs by $2.4 \%$ [3]. Temperature of steam in coal-fired power plant is expected to be in the range of $550-720^{\circ} \mathrm{C}$ and pressure is expected to be above $24 \mathrm{MPa}$ [3-5].

Grade 91 steels are a ferritic-martensitic (F-M) class of steel with superior creep strength [6,7]. The addition of strong carbide and carbonitride formers like vanadium (V), niobium $(\mathrm{Nb})$, and titanium (Ti) lead to the precipitation of various particles, such as $\mathrm{M}_{23} \mathrm{C}_{6}$, and $\mathrm{MX}$ type precipitates: $(\mathrm{Ti}, \mathrm{Nb})(\mathrm{N}, \mathrm{C}),(\mathrm{Nb}, \mathrm{V})(\mathrm{C}, \mathrm{N})$, and $(\mathrm{V}, \mathrm{Nb})(\mathrm{N}, \mathrm{C})$. The smaller interparticle spacing and increased volume fraction of the fine MX carbides enhance the alloy strength. These precipitates obstruct the movement of dislocations, refine grains during normalizing, and delay plastic deformation [6,8]. However, precipitates like Z-phase and Laves phase may lead to a decrease in the strength of the alloy by weakening the solid solution.

Evolution of various precipitates and microstructure can be understood from the heat treatment, differential scanning calorimetric (DSC) studies, and thermodynamic calculations using Thermo-Calc. The heat treatment study of Grade 91 steel helps in understanding its microstructural evolution and mechanical properties; as this material, whether being used for a reactor pressure vessel or boiler component, goes through a series of heating, cooling, and welding processes. With the changes involved in normalizing and tempering temperatures, different types of carbides such as $\mathrm{M}_{23} \mathrm{C}_{6}$, Z-phase, $\mathrm{Ti} / \mathrm{Nb} / \mathrm{V}$ rich $\mathrm{MX}$ type carbide/carbonitrides precipitate and coarsen in Grade 91 steel resulting in a change in the creep strength, ductility, hardness, and microstructure. Ahn et al. [9] observed a decrease in the high temperature strength of an $\mathrm{Nb}$ containing steel due to coarsening of $\mathrm{Nb}$-rich precipitates. DSC was used to measure the heat absorbed or liberated during heating or cooling associated with carbide precipitation and other phase changes. Ganesh et al. [10] were able to find the phase transformation temperatures including temperature ranges for dissolution of various precipitates in different low carbon steels.

The present article aims to elucidate the effects of various heat treatment conditions (normalizing and tempering) on Grade 91 steel. There are numerous studies on the normalizing/tempering of Grade 91 steel [11-15], but these studies are limited to few temperatures and times. Thus, this paper has taken about 50 normalizing and tempering conditions to study the relevant microstructural evolution. 
To that end, a combination of microstructural characterization efforts and microhardness measurements was utilized. The findings were discussed with the help of DSC studies, and ThermoCalc $^{\mathrm{TM}}$ was used to understand the microstructural evolution and precipitate stability.

\section{Experimental Details}

\subsection{Material}

The manufacturer-supplied chemical composition of ASTM A387 Grade 91 CL2 steel used in this study is shown in Table 1. The hot rolled Grade 91 plates were obtained from American Alloy Steel, Houston, TX, USA, in a normalized and tempered condition (i.e., austenitized at $1040{ }^{\circ} \mathrm{C}$ for $240 \mathrm{~min}$ followed by air cooling, and tempered at $790{ }^{\circ} \mathrm{C}$ for $43 \mathrm{~min}$ ). The as-received plates were $10.4 \mathrm{~cm} \times 10.4 \mathrm{~cm} \times 1.27 \mathrm{~cm}$ in size. Heat treatment specimens were cut out from these plates using a diamond wafering blade. At room temperature, the as-received Grade 91 steel had an average yield strength of $533 \mathrm{MPa}$, ultimate tensile strength of $683 \mathrm{MPa}$ and elongation to fracture of $19 \%$.

Table 1. Chemical composition (in wt.\%) of Grade 91 steel.

\begin{tabular}{ccc}
\hline Element & Nominal & Measured \\
\hline $\mathrm{Cr}$ & $8.00-9.50$ & 8.55 \\
$\mathrm{Mo}$ & $0.85-1.05$ & 0.88 \\
$\mathrm{~V}$ & $0.18-0.25$ & 0.21 \\
$\mathrm{Nb}$ & $0.06-0.10$ & 0.08 \\
$\mathrm{C}$ & $0.08-0.12$ & 0.10 \\
$\mathrm{Mn}$ & $0.30-0.60$ & 0.51 \\
$\mathrm{Cu}$ & 0.4 (max.) & 0.18 \\
$\mathrm{Si}$ & $0.20-0.50$ & 0.32 \\
$\mathrm{~N}$ & $0.03-0.07$ & 0.035 \\
$\mathrm{Ni}$ & 0.40 (max.) & 0.15 \\
$\mathrm{P}$ & 0.02 (max.) & 0.012 \\
$\mathrm{~S}$ & 0.01 (max.) & 0.005 \\
$\mathrm{Ti}$ & 0.01 (max.) & 0.002 \\
$\mathrm{Al}$ & 0.02 (max.) & 0.007 \\
$\mathrm{Zr}$ & 0.01 (max.) & 0.001 \\
$\mathrm{Fe}$ & Balance & Balance \\
\hline
\end{tabular}

\subsection{Heat Treatment}

Heat treatment was performed using an electric resistance furnace, capable of reaching a temperature exceeding $1200{ }^{\circ} \mathrm{C}$. Normalizing was first done on each sample within a temperature range of $1020-1100{ }^{\circ} \mathrm{C}$ for 2,4 , and $8 \mathrm{~h}$. Normalizing temperature and time were so chosen that austenitization had been complete before tempering was carried out. Normalized samples were air cooled down to room temperature before tempering at various temperatures and times. Samples that have been normalized at $1040{ }^{\circ} \mathrm{C}$ for 2,4 and $8 \mathrm{~h}$ were tempered at $690,725,745$ and $790{ }^{\circ} \mathrm{C}$ for 2,8 and $20 \mathrm{~h}$. Tempering of samples normalized at $1040^{\circ} \mathrm{C}$ for $2 \mathrm{~h}$ was expanded to include temperatures in the range of $635-850{ }^{\circ} \mathrm{C}$. This created a matrix of close to 50 possible combinations of normalizing and 
tempering scenarios, which provided an adequate sequence to reveal the microstructural changes during heat treatment.

\subsection{Metallographic Characterization}

Optical microscopy was performed with Olympus optical microscope, Center Valley, PA, USA, on both the as-received and heat treated specimens for characterization of the grain structure. Optical micrographs were taken for each sample and provided visual representation of the changing phases and microstructural features. Transmission electron microscopy (TEM) studies were done on selected samples. Conventional metallographic procedures of cold mounting, grinding and polishing were followed to prepare the specimen surface to $0.5 \mu \mathrm{m}$ finish before etching was carried out using Marble's reagent: A solution made of $50 \mathrm{~mL}$ distilled water, $50 \mathrm{~mL}$ hydrochloric acid and $10 \mathrm{~g}$ of copper sulfate. Subsequently, an Olympus light microscope, Center Valley, PA, USA was used to examine the metallographic specimens, and an attached CCD camera was used to record the images.

For the TEM study, the sectioned samples were mechanically polished down to $\sim 120 \mu \mathrm{m}$ thickness, and then $3 \mathrm{~mm}$ diameter disks were punched out of the samples. Those disks were then jet polished in Fischione twin-jet polisher using a solution of 80 volume $\%$ methanol and 20 volume $\%$ nitric acid solution at a temperature of about $-40{ }^{\circ} \mathrm{C}$. Dry ice bath was used to achieve low temperature. Philips CM200, San Francisco, CA, USA, and JEOL JEM-2010, Pleasanton, CA, USA, TEMs operated at an accelerating voltage of $200 \mathrm{kV}$ were used to study in detail the grain and precipitate morphology of the material under both as-received and select heat treated conditions. The scope of the study did not involve extensive TEM study of these samples. The EDS system available in the same TEMs was used to estimate the chemical composition of precipitates. Hardness was measured using a Leco Vickers microhardness tester, St. Joseph, MI, USA; the applied load was $500 \mathrm{gf}$ and the hold time was $15 \mathrm{~s}$.

\subsection{Thermodynamic Modeling}

The calculations of thermodynamic equilibrium in Grade 91 steel and construction of C-isopleths were done with the help of Thermo-Calc AB software (Thermo-Calc Classic Version S, Stockholm, Sweden). Thermo-Calc TCFE6 database (Stockholm, Sweden) for iron-based alloys was used to conduct all the equilibrium calculations. Due to the significant complexity of the Grade 91 steel (iron plus 13 alloying elements), impurities such as $\mathrm{S}$ or $\mathrm{P}$ were excluded from the thermodynamic calculations.

\subsection{Differential Scanning Calorimetry}

Differential scanning calorimetric study of Grade 91 steel was done using a Netzsch STA 409 PC calorimeter, San Francisco, CA, USA. The DSC chamber was evacuated and purged several times with the argon gas of high purity (99.999\%), and the flow rate of argon was maintained at $85 \mathrm{~cm}^{3} / \mathrm{min}$. The sample mass ranging between 50 and $60 \mathrm{mg}$ was found suitable for an acceptable signal to noise ratio. The sensitivity curves for scan rate of $20^{\circ} \mathrm{C} / \mathrm{min}$ were calibrated using the melting point of pure indium, tin, zinc, aluminum and gold under research grade argon atmosphere. Baseline calibrations were performed by using a pair of empty crucibles corresponding to the heating rate of $20{ }^{\circ} \mathrm{C} / \mathrm{min}$. Non-isothermal 
DSC measurements were done by heating the sample from 25 to $1400{ }^{\circ} \mathrm{C}$, and then cooling was undertaken at the same rate down to $200{ }^{\circ} \mathrm{C}$.

\section{Results}

\subsection{Microstructural Characteristics}

The as-received Grade 91 steel had a tempered martensitic microstructure with a lot of precipitates, as shown in Figure 1a,b. Precipitation hardening is one of the main strengthening mechanisms in highly alloyed steels like Grade 91. Alloying elements, such as $\mathrm{C}, \mathrm{N}, \mathrm{Ti}, \mathrm{Nb}, \mathrm{V}, \mathrm{Cr}$ and $\mathrm{Mo}$, promote the formation of precipitates like Cr-rich $\mathrm{M}_{23} \mathrm{C}_{6}$, and $\mathrm{Ti}$ or $\mathrm{Nb}$ or $\mathrm{V}$-rich $\mathrm{MX}$ particles, where $\mathrm{M}$ stands for metals, i.e., $\mathrm{Cr}$, $\mathrm{Mo}$, $\mathrm{Ti}$, $\mathrm{Nb}$ or $\mathrm{V}$. The $\mathrm{Cr}$-rich $\mathrm{M}_{23} \mathrm{C}_{6}$ precipitates were elongated rod-like or block-like particles, while Ti-rich, Nb-rich and V-rich MX precipitates had nearly spherical shape. The Cr-rich $\mathrm{M}_{23} \mathrm{C}_{6}$ type precipitates were mainly observed at the lath boundaries and prior austenite grain boundaries (PAGB). The dimension of the elongated rod-like and block-like Cr-rich precipitates was measured, and found to have an average length of $285 \pm 80 \mathrm{~nm}$ and width of $121 \pm 39 \mathrm{~nm}$, which is similar to that reported by Shen et al. [16] in 11Cr F-M steel and Anderson et al. [17] in Grade 91 steel. The average diameter of near-spherical MX-type precipitates was $37 \pm 15 \mathrm{~nm}$, similar to values reported in literature $[3,16]$. These types of precipitates were mainly located in the matrix and martensitic lath structure. These thermally stable fine precipitates enhance the long term creep resistance by impeding movement of mobile dislocations, prior austenite grain boundaries, martensite lath and subgrain boundaries, and restrict fine grain structure from recrystallization. For a constant normalizing time of $2 \mathrm{~h}$, prior austenite grain size and martensite lath size increased with increasing normalizing temperatures of $1020{ }^{\circ} \mathrm{C}-1100{ }^{\circ} \mathrm{C}$, as shown in Figure $2 \mathrm{a}-\mathrm{d}$. The as-normalized $\left(1040{ }^{\circ} \mathrm{C}\right.$ for $2 \mathrm{~h}$ ) microstructure had hard martensitic lath structures with high dislocation density, as observed in Figure 2c,d. Similarly, for constant normalizing temperature of $1040{ }^{\circ} \mathrm{C}$, martensite lath size and prior austenite grain size increased with increasing normalizing time of 2,4 and $8 \mathrm{~h}$. Figure $2 \mathrm{e}$ and $\mathrm{f}$ shows the optical and TEM micrograph of sample normalized at $1040{ }^{\circ} \mathrm{C}$ for $8 \mathrm{~h}$, respectively. Figure $2 \mathrm{~g}$ shows the EDS spectrum of a $\mathrm{M}_{23} \mathrm{C}_{6}$ type precipitate shown in Figure $2 \mathrm{f}$, indicating the presence of $\mathrm{Cr}$.

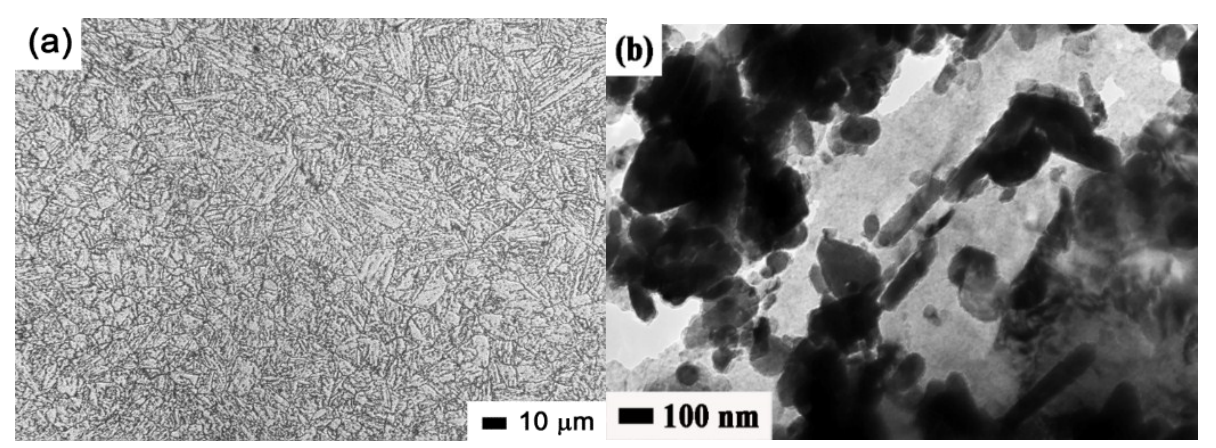

Figure 1. As-received microstructure: (a) optical and (b) TEM micrograph. 

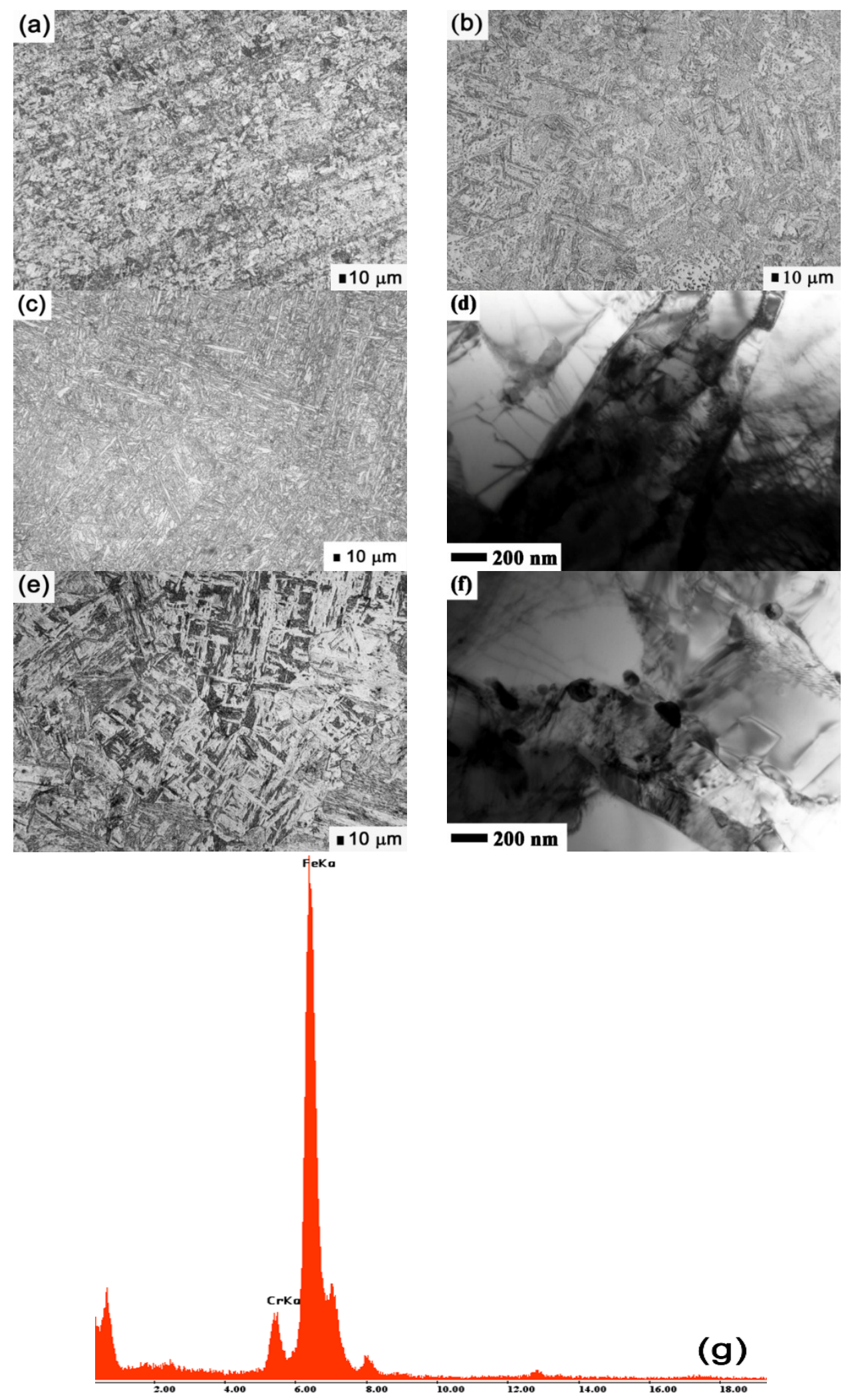

Figure 2. As-normalized optical micrograph (a) normalized at $1020{ }^{\circ} \mathrm{C}$ for $2 \mathrm{~h}$; (b) normalized at $1100{ }^{\circ} \mathrm{C}$ for $2 \mathrm{~h}$; (c) normalized at $1040{ }^{\circ} \mathrm{C}$ for $2 \mathrm{~h}$; (d) TEM micrograph of sample normalized at $1040{ }^{\circ} \mathrm{C}$ for $2 \mathrm{~h}$; (e) optical micrograph of sample normalized at $1040{ }^{\circ} \mathrm{C}$ for $8 \mathrm{~h}$; (f) TEM micrograph of a sample normalized at $1040{ }^{\circ} \mathrm{C}$ for $8 \mathrm{~h}$; and (g) the EDS spectrum of $\mathrm{M}_{23} \mathrm{C}_{6}$ type precipitate shown in Figure $2 \mathrm{f}$. 
The tempered microstructure of Grade 91 steel is shown in Figure 3. Figure 3a shows fine microstructure of sample normalized at $1040{ }^{\circ} \mathrm{C}$ for $2 \mathrm{~h}$ and tempered for $690{ }^{\circ} \mathrm{C}$. Figure $3 \mathrm{~b}$ shows coarse martensitic microstructure of sample normalized at $1040{ }^{\circ} \mathrm{C}$ for $2 \mathrm{~h}$ tempered at $745{ }^{\circ} \mathrm{C}$ for $8 \mathrm{~h}$. Figure $3 \mathrm{c}$ and $\mathrm{d}$ shows the martensitic lath structure of sample normalized at $1040{ }^{\circ} \mathrm{C}$ for $2 \mathrm{~h}$ and tempered at $790{ }^{\circ} \mathrm{C}$ for $2 \mathrm{~h}$. Grain size increased with increasing normalizing time, and tempering time. The sample normalized at $1040{ }^{\circ} \mathrm{C}$ for $2 \mathrm{~h}$ and tempered at $790{ }^{\circ} \mathrm{C}$ for $2 \mathrm{~h}$ has grain size of $\sim 11 \mu \mathrm{m}$, while sample normalized at $1040{ }^{\circ} \mathrm{C}$ for $8 \mathrm{~h}$ and tempered at $790{ }^{\circ} \mathrm{C}$ for $20 \mathrm{~h}$ resulted in a grain size of $\sim 17 \mu \mathrm{m}$. Figure $3 \mathrm{e}$ shows tempered martensitic structure of sample normalized at $1040{ }^{\circ} \mathrm{C}$ for $4 \mathrm{~h}$ and tempered at $725^{\circ} \mathrm{C}$ for $2 \mathrm{~h}$. Sample normalized at $1040{ }^{\circ} \mathrm{C}$ for $8 \mathrm{~h}$ and tempered at $790{ }^{\circ} \mathrm{C}$ for $20 \mathrm{~h} \mathrm{had}$ coarse grain structure, as shown in Figure $3 \mathrm{f}$.

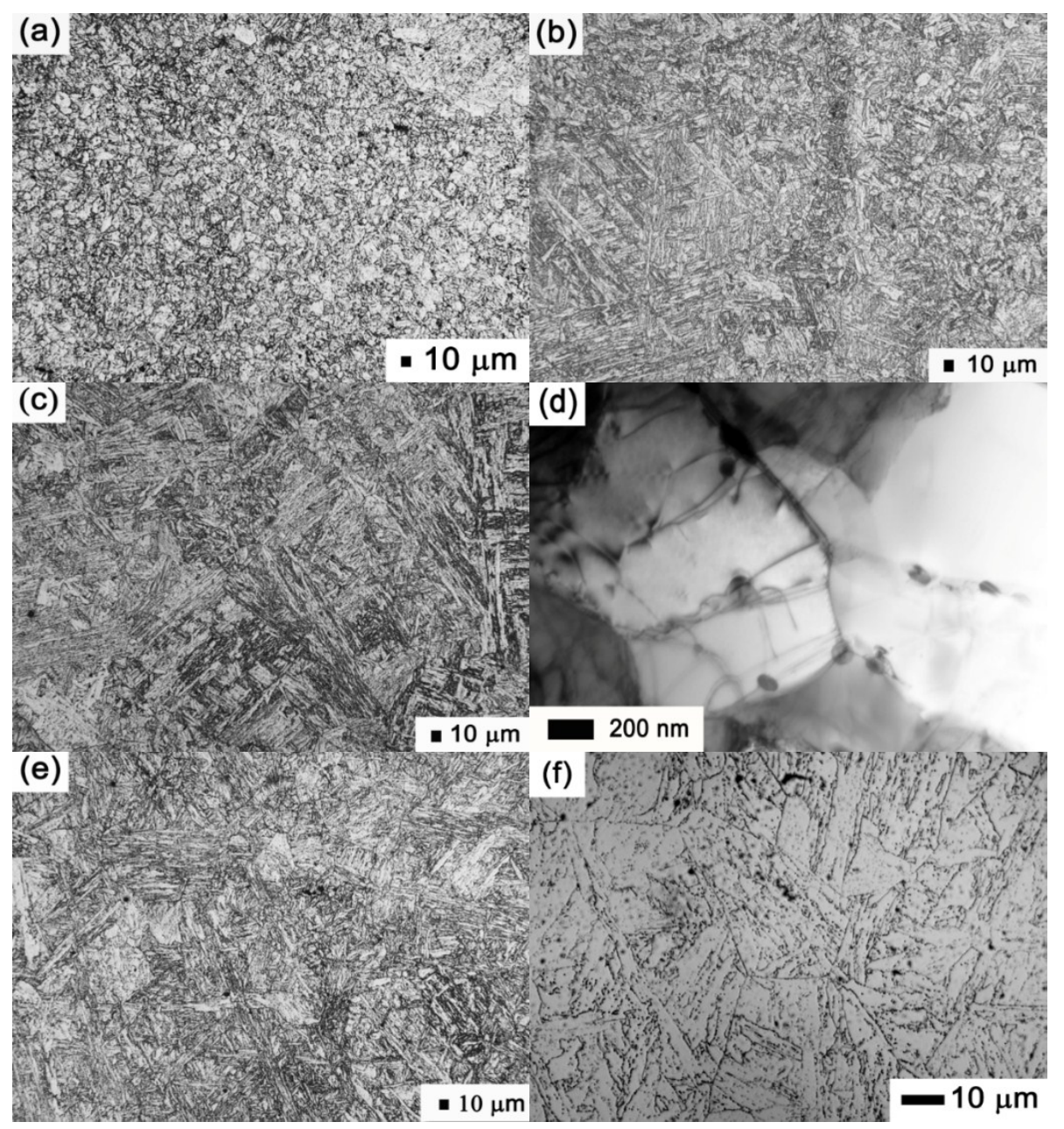

Figure 3. Tempered optical micrographs: (a) normalized at $1040{ }^{\circ} \mathrm{C}$ for $2 \mathrm{~h}$ and tempered at $690{ }^{\circ} \mathrm{C}$ for $2 \mathrm{~h}$; (b) normalized at $1040{ }^{\circ} \mathrm{C}$ for $2 \mathrm{~h}$ and tempered at $745{ }^{\circ} \mathrm{C}$ for $8 \mathrm{~h}$; (c) normalized at $1040^{\circ} \mathrm{C}$ for $2 \mathrm{~h}$ and tempered at $790{ }^{\circ} \mathrm{C}$ for $2 \mathrm{~h}$; (d) TEM micrograph of sample normalized at $1040{ }^{\circ} \mathrm{C}$ for $2 \mathrm{~h}$ and tempered at $790{ }^{\circ} \mathrm{C}$ for $2 \mathrm{~h}$; optical micrographs (e) normalized at $1040{ }^{\circ} \mathrm{C}$ for $4 \mathrm{~h}$ and tempered at $725^{\circ} \mathrm{C}$ for $2 \mathrm{~h}$; and (f) normalized at $1040{ }^{\circ} \mathrm{C}$ for $8 \mathrm{~h}$ and tempered at $790{ }^{\circ} \mathrm{C}$ for $20 \mathrm{~h}$. 


\subsection{Hardness of Heat Treated Steel}

Normalizing treatment is intended for austenitization and homogenization of the solid solution. However, the right combination of normalizing temperature and time has to be found to optimize the material mechanical properties. Hardness measurements were performed on the alloy samples normalized at $1020,1040,1050,1060,1080$ and $1100{ }^{\circ} \mathrm{C}$ while keeping the time constant at $2 \mathrm{~h}$. The hardness decreased with increasing normalizing temperature, as shown in Figure 4a. The hardness value was about the same for normalizing carried out at 1020 and $1040{ }^{\circ} \mathrm{C}$, but after that, the hardness gradually decreased until reaching $1100{ }^{\circ} \mathrm{C}$. The effect of change in normalizing time was studied by heat treating Grade 91 steel at $1040{ }^{\circ} \mathrm{C}$ for $2 \mathrm{~h}, 4 \mathrm{~h}$ and $8 \mathrm{~h}$. The hardness of the alloy decreased with increasing normalizing time, as shown in Figure $4 \mathrm{~b}$.

Alloy normalized at $1040{ }^{\circ} \mathrm{C}$ for $2 \mathrm{~h}$ was tempered at $690,725,745$ and $790{ }^{\circ} \mathrm{C}$ for $2 \mathrm{~h}, 8 \mathrm{~h}$ and $20 \mathrm{~h}$. Hardness of the alloy decreased with increasing tempering temperature and time, as shown in Figure 4c. Alloy tempered at 690 and $725{ }^{\circ} \mathrm{C}$ showed significant drop in hardness with increasing tempering time, but for 745 and $790{ }^{\circ} \mathrm{C}$ the decrease in hardness was gradual. Similar profiles were observed for samples normalized at $1040{ }^{\circ} \mathrm{C}$ for $4 \mathrm{~h}$ then tempered, and samples normalized at $1040{ }^{\circ} \mathrm{C}$ for $8 \mathrm{~h}$ then tempered at aforementioned temperatures, as shown in Figure $4 \mathrm{~d}$,e, respectively. Figure $4 \mathrm{~g}$ shows the hardness of all tempered samples. Among all samples normalized at $1040{ }^{\circ} \mathrm{C}$ and tempered, samples normalized for $2 \mathrm{~h}$ and tempered at $690{ }^{\circ} \mathrm{C}$ for $2 \mathrm{~h}$ had the highest hardness, while sample normalized for $8 \mathrm{~h}$ and tempered at $790{ }^{\circ} \mathrm{C}$ for $20 \mathrm{~h}$ had the lowest hardness. The tempering temperature of the sample normalized at $1040{ }^{\circ} \mathrm{C}$ for $2 \mathrm{~h}$ was expanded to temperatures slightly above $\mathrm{A}_{\mathrm{Cl}}$ temperatures. Hardness of the alloy normalized at $1040{ }^{\circ} \mathrm{C}$ for $2 \mathrm{~h}$ and tempered for $2 \mathrm{~h}$ decreased with increasing tempering temperature up to $745{ }^{\circ} \mathrm{C}$, stabilized till $820{ }^{\circ} \mathrm{C}$, then increased, as shown in Figure $4 \mathrm{f}$. Tempering above $\mathrm{A}_{\mathrm{C} 1}$ temperature was done to study the role of re-precipitation in Grade 91 steel.

\subsection{Differential Scanning Calorimetry}

Phase transformations of as-received (normalized and tempered) Grade 91 steel were studied using DSC. The phase transformations and reactions associated with heating and cooling of the alloy, as shown in Figure 5, are listed in Table 2. The listed temperatures for phase transformation and precipitate in Table 2 were obtained from the DSC curves, particularly with the help of its derivative in which inflection points are noticeably defined. The nature of the transformations was primarily corroborated by the Thermo-Calc calculations. The transformation of martensite to ferrite started at $550{ }^{\circ} \mathrm{C}$, and the Curie temperature $\left(\mathrm{T}_{\mathrm{c}}\right)$ signifying the change in ferromagnetic property was observed at $741{ }^{\circ} \mathrm{C}$. The austenite phase started to form at $820{ }^{\circ} \mathrm{C}\left(\mathrm{Ac}_{1}\right)$, peaked at $848{ }^{\circ} \mathrm{C}\left(\mathrm{Ac}_{\mathrm{p}}\right)$, and the transformation was complete at $870{ }^{\circ} \mathrm{C}\left(\mathrm{Ac}_{3}\right)$, which was confirmed by differential thermal analysis (DTA) and the results of our thermodynamic calculations. The dissolution of $\mathrm{M}_{23} \mathrm{C}_{6}$ precipitate was complete at $870{ }^{\circ} \mathrm{C}$. Dissolution of $(\mathrm{V}, \mathrm{Nb})(\mathrm{N}, \mathrm{C})$ type precipitates bottomed out at $998{ }^{\circ} \mathrm{C}$, but beyond that temperature they re-precipitated out. With the help of the first derivative of the heating curve, the onset of the second dissolution reaction of fine $(\mathrm{V}, \mathrm{Nb})(\mathrm{N}, \mathrm{C})$ type precipitates was found to be at $\sim 1140{ }^{\circ} \mathrm{C}$. From cooling curve and its first derivative, the martensite start temperature $\left(\mathrm{M}_{\mathrm{s}}\right)$ was calculated as $380^{\circ} \mathrm{C}$. Using $\mathrm{A}_{\mathrm{C} 1}$ as the onset temperature and $\mathrm{A}_{\mathrm{C} 3}$ as the end temperature, the DSC plot 
was used to calculate the enthalpy associated with the $\alpha$-ferrite $\rightarrow$ austenite phase transformation. The phase transformation enthalpy $\left(\Delta^{\mathrm{o}} H^{\alpha \rightarrow \gamma}\right)$ of $10 \mathrm{~J} / \mathrm{g}$ was calculated.
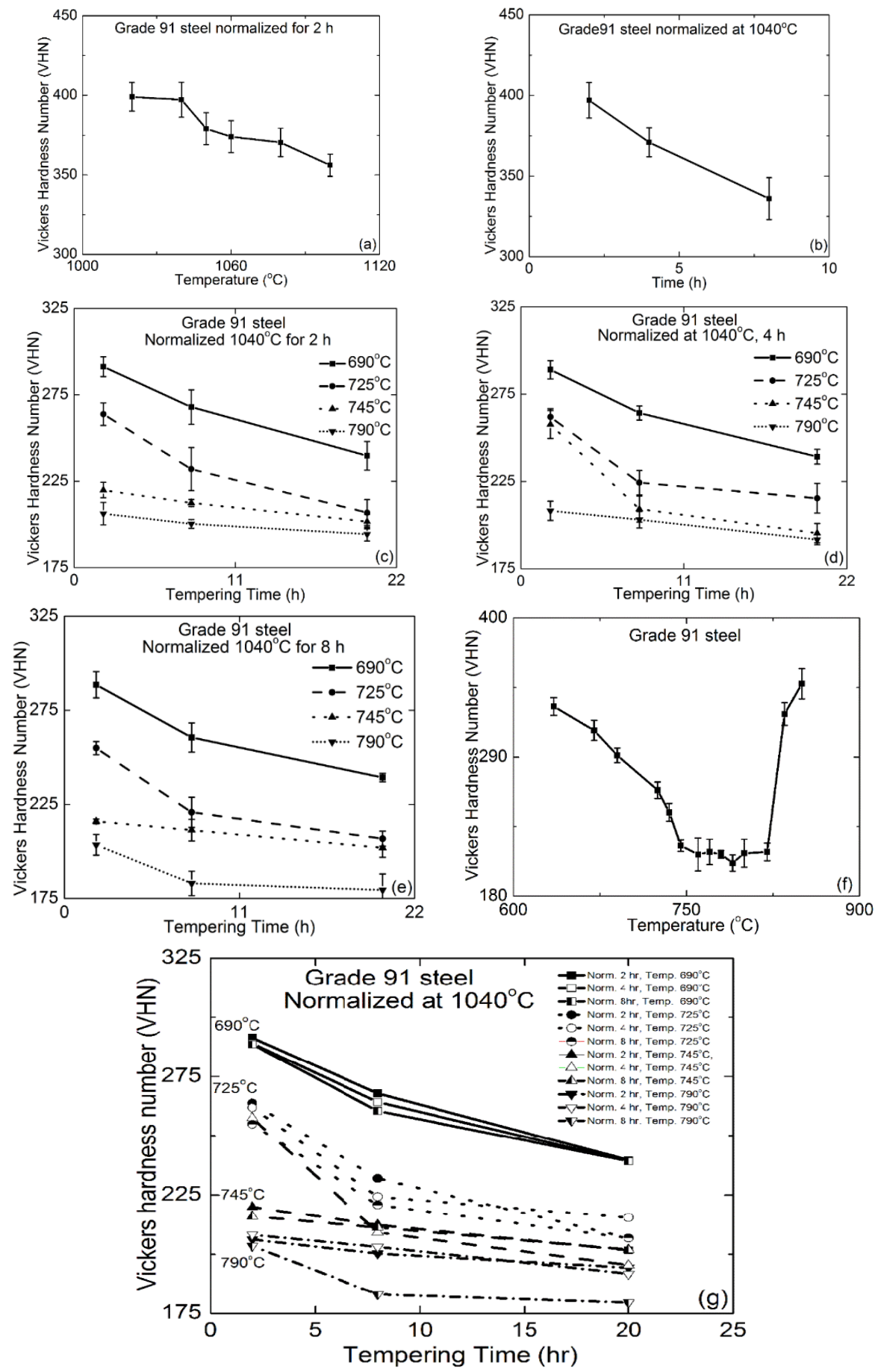

Figure 4. Variation in Vickers microhardness for various heat treatment conditions.

(a) Variation in normalizing temperature; (b) samples normalized at $1040{ }^{\circ} \mathrm{C}$ for various times;

(c) variation with tempering temperature and time for sample normalized at $1040{ }^{\circ} \mathrm{C}$ for $2 \mathrm{~h}$;

(d) Variation with tempering temperature and time for sample normalized at $1040{ }^{\circ} \mathrm{C}$ for $4 \mathrm{~h}$;

(e) variation with tempering temperature and time for sample normalized at $1040{ }^{\circ} \mathrm{C}$ for $8 \mathrm{~h}$;

(f) sample normalized at $1040{ }^{\circ} \mathrm{C}$ for $2 \mathrm{~h}$ and tempered at various temperatures for $2 \mathrm{~h}$; and

(g) normalized at $1040{ }^{\circ} \mathrm{C}$ and tempered samples. 


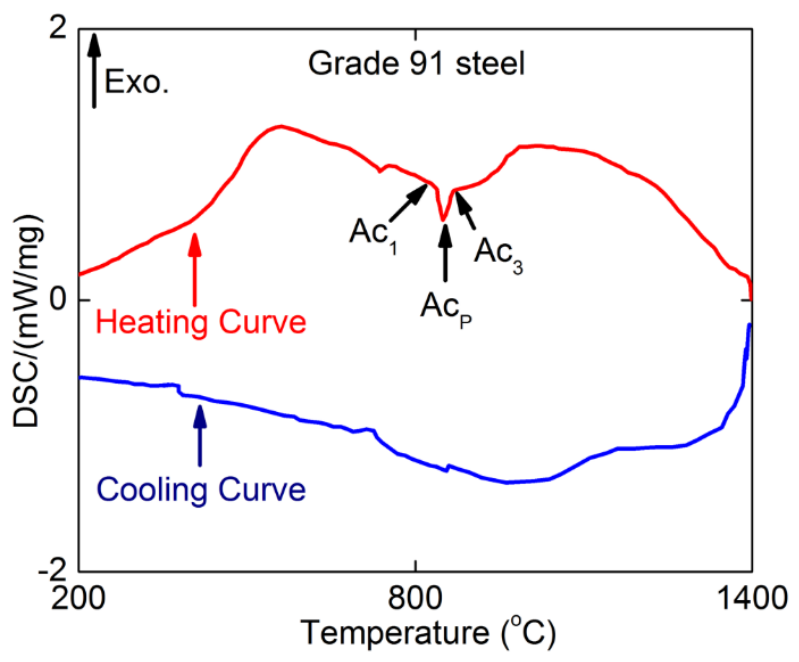

Figure 5. Differential scanning calorimetric plot of as-received Grade 91 steel.

Table 2. Various transformation temperatures of Grade 91 steel.

\begin{tabular}{cc}
\hline Description of Phase Change & Temperature $\left({ }^{\circ} \mathrm{C}\right)$ \\
\hline$\alpha^{\prime}+\mathrm{M}_{23} \mathrm{C}_{6}+(\mathrm{V}, \mathrm{Nb})(\mathrm{N}, \mathrm{C})+\mathrm{Z}$-phase $\rightarrow \alpha+\mathrm{M}_{23} \mathrm{C}_{6}+(\mathrm{V}, \mathrm{Nb})(\mathrm{N}, \mathrm{C})+\mathrm{Z}$-phase & 550 \\
$\mathrm{~T}_{\mathrm{c}}($ Curie Temperature $)$ & 741 \\
$\alpha+\mathrm{M}_{23} \mathrm{C}_{6}+(\mathrm{V}, \mathrm{Nb})(\mathrm{N}, \mathrm{C})+\mathrm{Z}$-phase $\rightarrow \alpha+\mathrm{M}_{23} \mathrm{C}_{6}+(\mathrm{V}, \mathrm{Nb})(\mathrm{N}, \mathrm{C})+(\mathrm{Nb}, \mathrm{V})(\mathrm{C}, \mathrm{N})$ & 770 \\
$\alpha+\mathrm{M}_{23} \mathrm{C}_{6}+(\mathrm{V}, \mathrm{Nb})(\mathrm{N}, \mathrm{C})+(\mathrm{Nb}, \mathrm{V})(\mathrm{C}, \mathrm{N}) \rightarrow \alpha+\gamma+(\mathrm{V}, \mathrm{Nb})(\mathrm{N}, \mathrm{C})+(\mathrm{Nb}, \mathrm{V})(\mathrm{C}, \mathrm{N})+\mathrm{M}_{23} \mathrm{C}_{6}$ & $820\left(\mathrm{~A}_{\mathrm{c} 1}\right)$ \\
$\alpha+\gamma+(\mathrm{V}, \mathrm{Nb})(\mathrm{N}, \mathrm{C})+(\mathrm{Nb}, \mathrm{V})(\mathrm{C}, \mathrm{N})+\mathrm{M}_{23} \mathrm{C}_{6} \rightarrow \gamma+(\mathrm{V}, \mathrm{Nb})(\mathrm{N}, \mathrm{C})+(\mathrm{Nb}, \mathrm{V})(\mathrm{C}, \mathrm{N})$ & $870\left(\mathrm{~A}_{\mathrm{c} 3}\right)$ \\
$\gamma+(\mathrm{V}, \mathrm{Nb})(\mathrm{N}, \mathrm{C})+(\mathrm{Nb}, \mathrm{V})(\mathrm{C}, \mathrm{N}) \rightarrow \gamma+(\mathrm{Ti}, \mathrm{Nb})(\mathrm{N}, \mathrm{C})+(\mathrm{Nb}, \mathrm{V})(\mathrm{C}, \mathrm{N})$ & 1045 \\
$\gamma+(\mathrm{Ti}, \mathrm{Nb})(\mathrm{N}, \mathrm{C})+(\mathrm{Nb}, \mathrm{V})(\mathrm{C}, \mathrm{N}) \rightarrow \delta+\gamma+(\mathrm{Ti}, \mathrm{Nb})(\mathrm{N}, \mathrm{C})$ & 1270 \\
$\delta+\gamma+(\mathrm{Ti}, \mathrm{Nb})(\mathrm{N}, \mathrm{C}) \rightarrow \gamma+\delta$ & 1397 \\
Martensite start $\left(\mathrm{M}_{\mathrm{s}}\right)$ & 380 \\
\hline
\end{tabular}

\subsection{Thermo-Calc Calculations}

The carbon isopleth for the Fe-Cr-Mn-Mo-Nb-Ni-Ti-V-N-C full system is shown in Figure 6a. It is a property diagram, which represents the analog of the binary Fe-C phase diagram, but constructed for the full alloy system. It was calculated using the previously mentioned TCFE6 thermodynamic database. The bcc ferrite phase starts dissolving at $\sim 810{ }^{\circ} \mathrm{C}$ and exists up to $\sim 855{ }^{\circ} \mathrm{C}$ and then reappears above $1270{ }^{\circ} \mathrm{C}$, as noted in Table 2 . In between 850 and $1270{ }^{\circ} \mathrm{C}$, the fcc austenite phase becomes stable. Other phases that are featured in the diagram in Figure $6 \mathrm{a}-\mathrm{c}$ are the Z-phase; the $\mathrm{M}_{23} \mathrm{C}_{6}$-phase; (with metal $\mathrm{M}$ being mostly $\mathrm{Cr}$ ); the Ti-rich $(\mathrm{Ti}, \mathrm{Nb})(\mathrm{N}, \mathrm{C}$ ) precipitates; the $\mathrm{Nb}$-rich and the $\mathrm{Nb}$-poor $(\mathrm{Nb}, \mathrm{V})(\mathrm{C}, \mathrm{N})$ precipitates; and the $\mathrm{V}$-rich $(\mathrm{V}, \mathrm{Nb})(\mathrm{N}, \mathrm{C})$ precipitates. All of the four phases have variable compositions but the same fcc crystalline lattice. The following notation was adopted for the latter four phases: In those cases when there was more carbon than nitrogen on a particular sublattice, the $(\mathrm{C}, \mathrm{N})$ notation was used; in the opposite case, the $(\mathrm{N}, \mathrm{C})$ notation was used. Similarly, the first position on the metal sublattice is assigned to a chemical element the concentration of which is the highest, e.g., $(\mathrm{Nb}, \mathrm{V})$; in the opposite case, the $(\mathrm{V}, \mathrm{Nb})$ notation was used. 

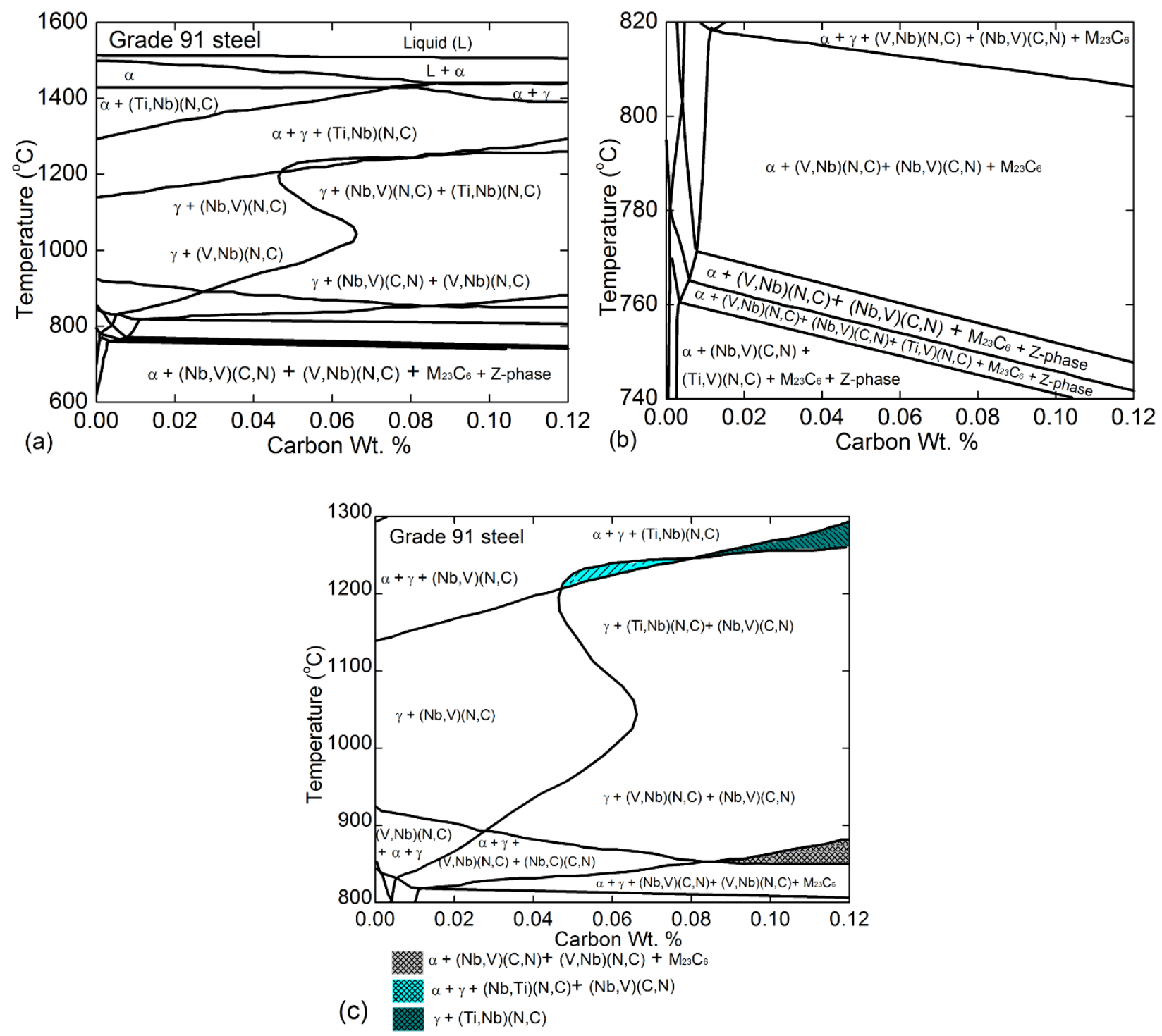

Figure 6. Carbon isopleth for Grade 91 steel. (a) Complete diagram: $600-1600{ }^{\circ} \mathrm{C}$; (b) $740-820^{\circ} \mathrm{C}$; (c) $800-1300{ }^{\circ} \mathrm{C}$.

It was established that the Ti-bearing precipitates $(\mathrm{Ti}, \mathrm{Nb})(\mathrm{C}, \mathrm{N})$ were more stable than the $(\mathrm{Nb}, \mathrm{V})(\mathrm{C}, \mathrm{N})$, and $(\mathrm{V}, \mathrm{Nb})(\mathrm{N}, \mathrm{C})$ precipitates in the higher temperature range. Figure 7 a shows a TEM micrograph of the as-normalized (normalized at $1040{ }^{\circ} \mathrm{C}$ for $2 \mathrm{~h}$ ) sample with Ti-rich MX precipitates. The EDS spectrum of the Ti-MX particle is shown in Figure 7b. This example demonstrates the significance of simulations for the computational thermodynamics driven alloy design.

The evolution of the ferrite phase and its volume fraction with respect to temperature is shown in Figure $8 \mathrm{a}$, and the evolution of $\mathrm{M}_{23} \mathrm{C}_{6}$ precipitate is shown in Figure $8 \mathrm{~b}$. The volume fraction of Z-phase, $(\mathrm{Nb}, \mathrm{V})(\mathrm{N}, \mathrm{C})+(\mathrm{Ti}, \mathrm{Nb})(\mathrm{N}, \mathrm{C})$, and $(\mathrm{V}, \mathrm{Nb})(\mathrm{N}, \mathrm{C})$ precipitates are illustrated by Figure $8 \mathrm{c}, \mathrm{d}$. Thermo-Calc calculations predicted that the volume fraction of $\mathrm{M}_{23} \mathrm{C}_{6}$ precipitate was higher than that of $\mathrm{V}$-rich and $\mathrm{Nb}$-rich $\mathrm{MX}$ type precipitates, owing to the higher wt.\% of $\mathrm{Cr}$ and $\mathrm{Mo}$ compared to $\mathrm{Nb}$ and V. Higher resolution plot of the evolution of $(\mathrm{V}, \mathrm{Nb})(\mathrm{N}, \mathrm{C})$ precipitate is shown in Figure $8 \mathrm{~d}$. Special attention was paid to the possibility of a phase separation and/or atomic clustering. Indeed, phase separation reaction and the miscibility gap were observed for the Fe-Cr system, so this possibility could not be excluded for the Fe-9Cr-1Mo steel. 


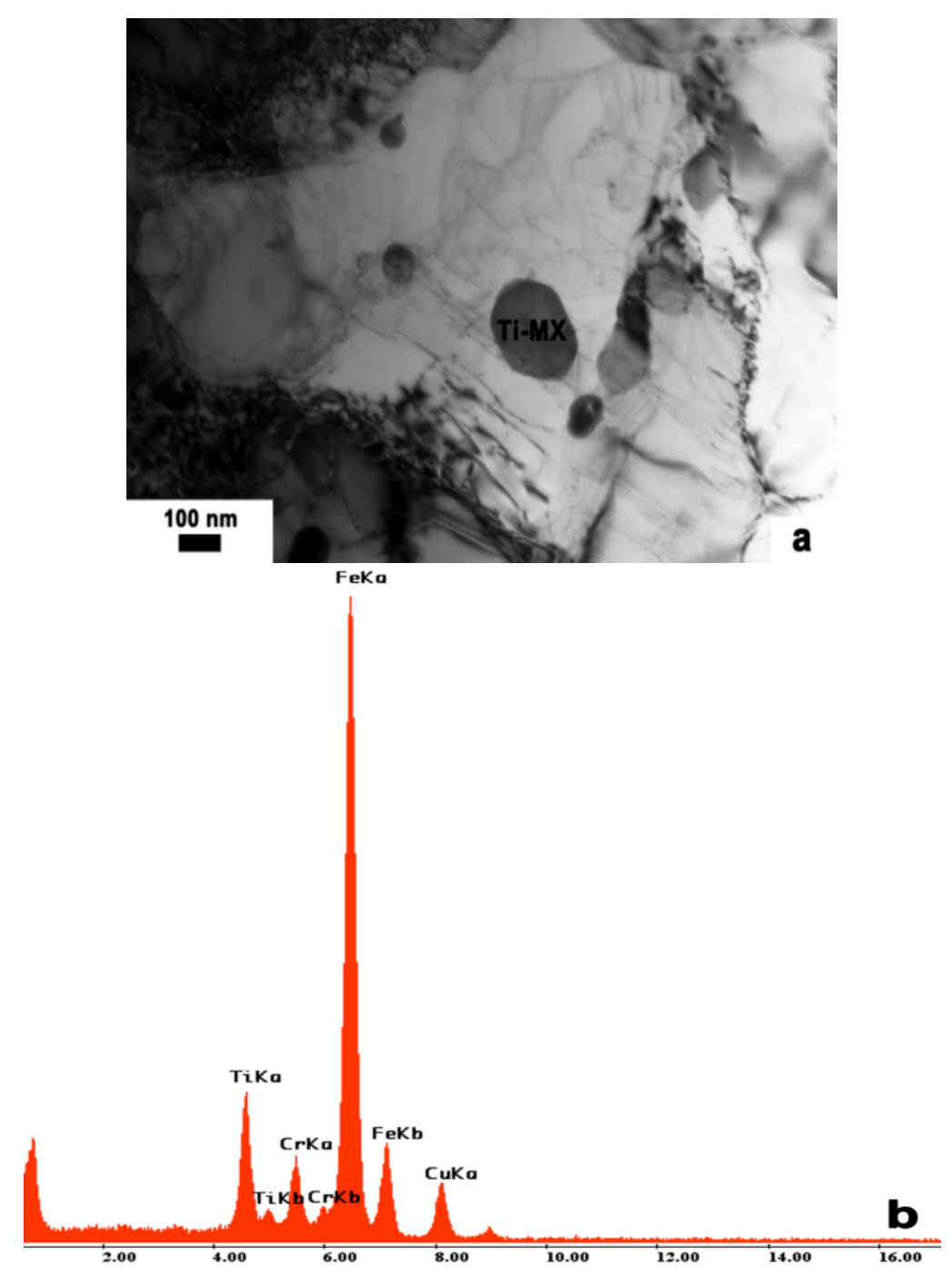

Figure 7. (a) A TEM micrograph of as-normalized (at $1040{ }^{\circ} \mathrm{C}$ for $2 \mathrm{~h}$ ) sample; and (b) EDS of a Ti-rich MX precipitate.

\section{Discussion}

\subsection{As-Normalized Microstructure}

Hardness of the Grade 91 steel normalized for $2 \mathrm{~h}$ at 1020, 1040, 1050, 1060, 1080 and $1100{ }^{\circ} \mathrm{C}$ decreased with increasing temperature. Similarly, hardness of the as-normalized sample at $1040{ }^{\circ} \mathrm{C}$ decreased with increasing normalizing time. As-normalized microstructure had hard martensitic lath structures with high dislocation density, as shown in Figure 2d. Yoshino et al. [11] and Das et al. [18] reported increase in the prior austenite grain size with increase in normalizing temperatures from 1050 to $1250{ }^{\circ} \mathrm{C}$. However, hardness remained constant in the same temperature range. However, in the current study, for normalizing carried out for $2 \mathrm{~h}$ in the temperature range of $1020-1100{ }^{\circ} \mathrm{C}$, hardness decreased with increasing normalizing temperature. The decrease in the hardness value and increase in prior austenite grain size was due to a decrease in the volume fraction of precipitates with increased normalizing temperature and time. Average diameter of MX precipitates increased from $35 \mathrm{~nm}$ after normalizing at $1050{ }^{\circ} \mathrm{C}$ to $315 \mathrm{~nm}$ after normalizing at $1200{ }^{\circ} \mathrm{C}$ [11], leading to a decrease in the number density of precipitates. 

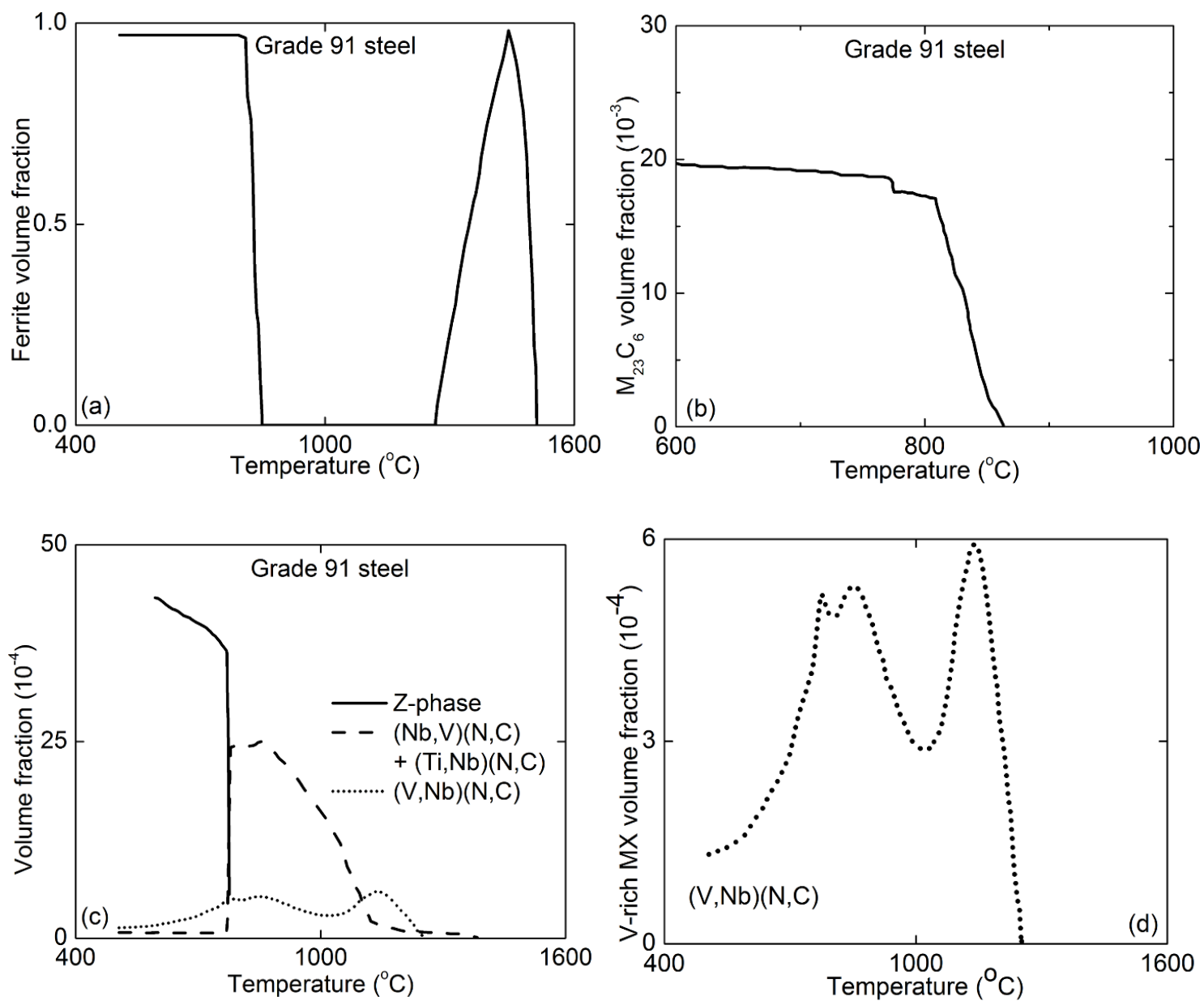

Figure 8. Evolutions of (a) the ferrite phase; (b) $\mathrm{M}_{23} \mathrm{C}_{6}$ precipitate; (c) Z-phase, Nb-rich $\mathrm{MX}, \mathrm{V}$-rich MX, and Ti-rich MX precipitates; and (d) high resolution plot of $(\mathrm{V}, \mathrm{Nb})(\mathrm{N}, \mathrm{C})$ precipitate as a function of temperature.

Given the higher carbon solubility in austenite than in alpha ferrite, carbide precipitates dissolve in austenite. With increased diffusion at a higher temperature and longer time, the precipitates coarsen while the lath size and grain size also increase. Grade 91 steel normalized at $1040{ }^{\circ} \mathrm{C}$ for $8 \mathrm{~h} \mathrm{had} \mathrm{a}$ martensitic lath width of $473 \pm 105 \mathrm{~nm}$, and the size of the needle shaped $\mathrm{M}_{23} \mathrm{C}_{6}$ precipitates was $136 \pm 75 \mathrm{~nm}$ in length and $28 \pm 20 \mathrm{~nm}$ in width. While the sample normalized at $1040{ }^{\circ} \mathrm{C}$ for $2 \mathrm{~h} \mathrm{had} \mathrm{a}$ martensitic lath size of $335 \pm 115 \mathrm{~nm}$, while the $\mathrm{M}_{23} \mathrm{C}_{6}$ precipitates were $78 \pm 15 \mathrm{~nm}$ in length and $13 \pm 4 \mathrm{~nm}$ in width. At higher normalizing temperature, considerable grain growth occurred, but at lower normalizing temperature the austenite grain structure was finer. Moreover, normalizing below $900{ }^{\circ} \mathrm{C}$ resulted in partially transformed ferrite with patches of martensitic structure [12]. However, the change in the normalizing temperature in the range of $1020-1100{ }^{\circ} \mathrm{C}$ can result in different precipitate size distribution(s) that could possibly affect the mechanical behavior of the alloys.

\subsection{Tempered Microstructure}

The as-normalized hard martensitic lath structure with high dislocation density changed to stress-free, relaxed tempered martensitic structure upon tempering. Upon tempering, the normalized steel is reheated to a temperature just below $\mathrm{Ac}_{1}$, which relieves stress in martensitic structure via carbon 
diffusion and carbide formation. With increased tempering time, the diffusion of carbon is increased and simultaneously became stress relieved. For example, a P92 steel normalized at $1050{ }^{\circ} \mathrm{C}$ showed a decrease in hardness with increasing tempering temperature from 525 up to $720^{\circ} \mathrm{C}$. Similarly, the tensile strength and yield strength decreased with increasing tempering temperature [13]. Moreover, for Grade 91 steel tempered at 765,730 , and $680^{\circ} \mathrm{C}$, specimens tempered at the lowest temperature had the highest creep strength at $600{ }^{\circ} \mathrm{C}$, as shown by Sawada et al. [14]. Tempering above Ac temperature decreased the toughness of the material due to the formation of fresh martensite as found by Silwal et al. [19]. In the present work, the hardness decreased with increasing tempering temperature till $\mathrm{Ac}_{1}$ temperature $\left(820^{\circ} \mathrm{C}\right)$. The decrease in hardness, as seen in Figure $4 \mathrm{~g}$, is due to the coarsening of precipitates, dissolution of $\mathrm{M}_{23} \mathrm{C}_{6}$ carbides, and breakdown of martensitic lath structure.

Coarser precipitates are not effective in impeding the mobility of dislocations, and affect the strength of the steel [6]. Decrease in hardness with increased temperature can also in part be associated with the increased molybdenum in carbides. In Fe-Mo-C steels tempered at $700{ }^{\circ} \mathrm{C}$, Shtansky and Inden [20] observed $4 \%$ increase in the molybdenum content in $\mathrm{M}_{23} \mathrm{C}_{6}$ precipitates after increasing the tempering time from 25 to $500 \mathrm{~h}$. Increased molybdenum content in precipitates implies removal of Mo from the matrix, thus weakening the solid solution. Moreover, the $\mathrm{M}_{23} \mathrm{C}_{6}$ precipitates located on the prior austenite grain boundaries penetrate into the grains with increasing tempering time. The stability of hardness at temperatures around $800{ }^{\circ} \mathrm{C}$ reflects the maximum precipitation rate for $0.1 \mathrm{wt} . \% \mathrm{C}$ in the alloy. However, above $820^{\circ} \mathrm{C}$, the hardness increased because of secondary hardening resulting from increased volume fraction of $(\mathrm{V}, \mathrm{Nb})(\mathrm{N}, \mathrm{C})$ and $(\mathrm{Nb}, \mathrm{V})(\mathrm{N}, \mathrm{C})$ precipitates, as noted in Figure $8 \mathrm{c}$ for the respective precipitates. The tempered microstructure still consisted of precipitates and subgrain structures but with reduced dislocation density, as seen in Figure 3d. MX type precipitates were observed inside the subgrain structure and martensite lath structure. $\mathrm{M}_{23} \mathrm{C}_{6}$ precipitates were mainly located on the prior austenite grain boundaries and martensitic lath boundaries. The microstructure of Grade 91 steel tempered at the lowest temperature had much finer martensite lath size and higher dislocation density. The as-received material had a prior austenitic grain size of $\sim 11 \mu \mathrm{m}$, while that of the sample normalized at $1040{ }^{\circ} \mathrm{C}$ for $8 \mathrm{~h}$ and tempered at $790{ }^{\circ} \mathrm{C}$ for $20 \mathrm{~h}$ was $17 \mu \mathrm{m}$. The martensitic lath size increased and dislocation density decreased upon tempering. Dudko et al. [13] noted that when tempered at $720{ }^{\circ} \mathrm{C}$ for $3 \mathrm{~h}$, the lath size increased to $300 \mathrm{~nm}$ from $250 \mathrm{~nm}$, and the dislocation density decreased to $6.2 \times 10^{14} \mathrm{~m}^{-2}$ from $7.0 \times 10^{14} \mathrm{~m}^{-2}$ compared to the as-normalized microstructure. In $9 \%-12 \% \mathrm{Cr}$ heat resistant steels, the dislocation density, hardness, and creep rupture life were generally reduced, but ductility and subgrain size increased with increasing tempering temperature [3].

The transformation of martensite to alpha-ferrite is dependent on the tempering temperature and holding time. The tempering temperature and holding time of tempering can be described by a single empirical parameter known as the Hollomon-Jaffe parameter $(P)$

$$
P=T(C+\log t)
$$

where $T(\mathrm{~K})$ is temperature, $C(40)$ constant, and $t$ (s) time. Generally, in the Hollomon-Jaffe parameter, 20 is used as the constant $(C)$, but in this study $C(40)$ gave the best fit. Figure 9 shows the Hollomon-Jaffe parameter for Grade 91 steel normalized at $1040{ }^{\circ} \mathrm{C} / 2 \mathrm{~h}$, and tempered in the temperature range of $635-820^{\circ} \mathrm{C}$ for 2,8 and $20 \mathrm{~h}$. Figure 9 can be used to describe the variation of hardness in the tempered Grade 91 steel as a function of tempering temperature/time (as shown in 
Figures 3 and 4). In the plot in Figure 9, two distinct regions could be observed: A region with a steep decrease in hardness with increasing Hollomon-Jaffe parameter followed by a region where the hardness did not vary much. The lower Hollomon-Jaffe parameter signifies lower tempering temperature/time where microstructural evolution takes place gradually and did not achieve quite the equilibrium microstructure. However, at higher Hollomon-Jaffe parameter the microstructure achieves close-to-equilibrium structure and the microstructural parameters did not change so much to affect hardness to an appreciable extent. Figure 8 shows the Thermo-Calc calculations indicating a decrease in the volume fraction of precipitates around $\mathrm{A}_{\mathrm{C} 1}$ temperature. The data related to tempering condition above $A_{C 1}$ have not been included in Figure 9 as the Hollomon-Jaffe parameter does not apply to heat treatment above $\mathrm{A}_{\mathrm{C} 1}$ temperature.

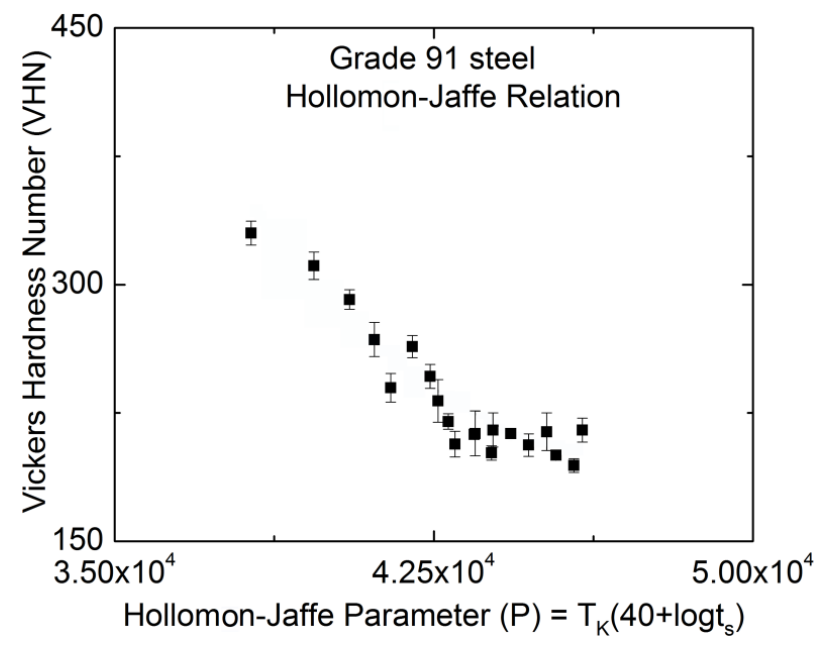

Figure 9. Hollomon-Jaffe relation of Grade 91 steel normalized at $1040{ }^{\circ} \mathrm{C}$ for $2 \mathrm{~h}$ and tempered at various temperatures and times.

\subsection{DSC Study}

The DSC plot shown in Figure 5 tracked the phase changes and reactions happening during heating and cooling of Grade 91 steel. Various temperatures associated with phase changes and reactions are listed in Table 2. DSC plot can slightly change depending on the heat treatment history of the material. Masuyama [15] reported that for various tempering temperatures, $\mathrm{Ac}_{1}$ temperature was between 820 and $851{ }^{\circ} \mathrm{C}$ and the martensite transformation was $\sim 400{ }^{\circ} \mathrm{C}$. In this study, the $\mathrm{Ac}_{1}$ temperature was $820{ }^{\circ} \mathrm{C}$ and the $\mathrm{M}_{\mathrm{s}}$ temperature was $380{ }^{\circ} \mathrm{C}$. DSC study of Grade 91 steel showed the change in the enthalpy associated with $\alpha$-ferrite to austenite phase transformation is dependent on the starting microstructure produced by thermal aging [21]. A list of enthalpy change associated with $\alpha$-ferrite to austenite phase transformation $\left(\Delta^{\mathrm{o}} H^{\alpha \rightarrow \gamma}\right)$ is included in Table 3. The $\Delta^{\mathrm{o}} H^{\alpha \rightarrow \gamma}$ for or pure iron was $16 \mathrm{~J} \cdot \mathrm{g}^{-1}$, but decreased with increased addition of alloying elements. Table 3 includes the enthalpy values of phase transformation (alpha-ferrite to austenite) for various steels. Substitutional solutes (such as $\mathrm{W}, \mathrm{Mo}, \mathrm{V}, \mathrm{Ti}, \mathrm{Ta}, \mathrm{Si}$ ) present in the steels in one or other combination are all ferrite-stabilizers. Even though steels contain carbon (an austenite stabilizer), the amount of $\mathrm{C}$ is fairly low. Thus, the addition of ferrite stabilizers to pure iron decreases the enthalpy, requiring more energy to transform to austenite and leading to a higher $\mathrm{Ac}_{1} / \mathrm{Ac}_{3}$ temperature. The volume fraction of $(\mathrm{V}, \mathrm{Nb})(\mathrm{C}, \mathrm{N})$ 
precipitates peaked initially at $790{ }^{\circ} \mathrm{C}$ and $850{ }^{\circ} \mathrm{C}$, then started to dissolve in the matrix with the dissolution bottoming out at $\sim 1000{ }^{\circ} \mathrm{C}$ and then peaked at $\sim 1140{ }^{\circ} \mathrm{C}$; these temperatures were captured with the help of the first derivative of the DSC heating curve. Furthermore, these temperatures were predicted by the Thermo-Calc calculations as shown in Figure 8c,d. The activation energy of $\mathrm{Nb}$ diffusion in the alpha-iron lattice is larger than those of Mo and $\mathrm{Cr}$ diffusion, and self-diffusion of iron [22]. Thus, the dissolution of $\mathrm{Nb}$ rich precipitates takes place at a higher temperature compared to the $\mathrm{M}_{23} \mathrm{C}_{6}$ precipitates. The $\mathrm{MX}$ type precipitates rich in $\mathrm{V}$ dissolve in the matrix before $\mathrm{Nb}$, given the smaller atomic radius of $\mathrm{V}$ compared to $\mathrm{Nb}$.

Table 3. Comparison of enthalpy associated with $\alpha \rightarrow \gamma$ phase change.

\begin{tabular}{|c|c|c|}
\hline Steel Composition (wt.\%) & $\Delta^{0} H^{\alpha \rightarrow \gamma}\left(J \cdot g^{-1}\right)$ & Reference \\
\hline Pure Iron & 16 & [21] \\
\hline $9 \mathrm{Cr}-1 \mathrm{Mo}$ & 15 & {$[10]$} \\
\hline $9 \mathrm{Cr}-1 \mathrm{Mo}-0.001 \mathrm{~V}-0.1 \mathrm{C}$ & 15 & [21] \\
\hline $9 \mathrm{Cr}-1 \mathrm{Mo}-0.1 \mathrm{C}-0.42 \mathrm{Si}$ & 13 & {$[10]$} \\
\hline $9 \mathrm{Cr}-1 \mathrm{~W}-0.23 \mathrm{~V}-0.06 \mathrm{Ta}-0.1 \mathrm{C}$ & 12 & {$[23]$} \\
\hline $9 \mathrm{Cr}-1 \mathrm{Mo}-0.21 \mathrm{~V}-0.08 \mathrm{Nb}-0.1 \mathrm{C}-0.002 \mathrm{Ti}$ & 10 & Present study \\
\hline
\end{tabular}

\subsection{Thermo-Calc Calculations}

In the present study, the normalizing temperatures $\left(1020,1040,1050,1060,1080\right.$, and $\left.1100{ }^{\circ} \mathrm{C}\right)$ and the temperature range of the subsequent tempering $\left(690,725,745\right.$, and $\left.790{ }^{\circ} \mathrm{C}\right)$ were of most interest. Figures 6 and 8 show the evolution of various phases as a function of temperature. These phase and precipitates play an important role in the formation of microstructure and strength of the heat treated alloy. The Thermo-Calc calculations predicted the existence of the Z-phase, but it was not observed in the TEM studies. During cooling, the austenite phase undergoes partial dissolution (the onset of transformation) at temperature $\sim 850{ }^{\circ} \mathrm{C}$ and disappears completely at $\sim 810{ }^{\circ} \mathrm{C}$, in almost complete agreement with the findings of the DSC experiments (temperatures 870 and $820{ }^{\circ} \mathrm{C}$, respectively). The Thermo-Calc does not make any distinction between $\alpha$-ferrite and the $\delta$-ferrite because they have the same bcc lattice. It would be appropriate to say that the $\alpha$-ferrite dissolved at $\sim 850{ }^{\circ} \mathrm{C}$, but the $\delta$-ferrite appeared at $\sim 1270{ }^{\circ} \mathrm{C}$ peaked at $\sim 1440{ }^{\circ} \mathrm{C}$ and then gradually dissolved as seen in Figure 8 a.

The mass fraction of $\mathrm{M}_{23} \mathrm{C}_{6}$ precipitates remained constant up to the $\mathrm{Ac}_{1}$ temperature but decreased drastically as austenite phase started forming. Given that austenite has higher affinity for $\mathrm{C}$ than $\alpha$-ferrite, the $\mathrm{M}_{23} \mathrm{C}_{6}$ precipitates exist up to $865^{\circ} \mathrm{C}$, and then dissolve into the austenitic matrix. The mass fraction of MX type precipitates was constant till $\mathrm{Ac}_{3}$ temperature, but then gradually decreased with increased temperature and totally dissolved at $\sim 1200{ }^{\circ} \mathrm{C}$ [24]. In the present study, the volume fraction of $\mathrm{Nb}$-rich $\mathrm{MX}$ increased at $\sim 770{ }^{\circ} \mathrm{C}$, started to decrease rapidly after $\sim 850{ }^{\circ} \mathrm{C}$, then gradually at $\sim 1120^{\circ} \mathrm{C}$ till $1260{ }^{\circ} \mathrm{C}$. Since there was no clear distinction between the evolution of (Ti,Nb)(N,C) precipitate and $(\mathrm{Nb}, \mathrm{V})(\mathrm{N}, \mathrm{C})$ precipitate, one could speculate that $1120^{\circ} \mathrm{C}$ marks the onset of the phase separation reaction. As indicated in Figure $8 \mathrm{c}, \mathrm{d}$, the line indicating both $(\mathrm{Nb}, \mathrm{V})(\mathrm{N}, \mathrm{C})$ and $(\mathrm{Ti}, \mathrm{Nb})(\mathrm{N}, \mathrm{C})$ precipitates has a tail to it. The tail indicates the presence of Ti-rich MX which is stable up to $\sim 1400{ }^{\circ} \mathrm{C}$, as shown in Figure 6 a. At around $470{ }^{\circ} \mathrm{C}$, the dissolution of the $\mathrm{M}_{6} \mathrm{C}$ precipitates was 
observed in the Thermo-Calc calculations, not the Laves phase (absent at any temperature for $\mathrm{x}(\mathrm{C})=0.001 \mathrm{wt} . \%)$. Laves phase was not observed in the as-received $9 \% \mathrm{Cr}$ alloys containing $0.1 \%$ and $0.05 \% \mathrm{C}$ with $0.03 \% \mathrm{Ti}$ [3]. The Z-phase disappeared as the Nb-rich MX precipitates started to form. It remains to be established whether at such a low temperature there is enough time for the formation of such precipitates $\left(\mathrm{M}_{6} \mathrm{C}\right)$. However, they were identified in the computed phase diagram quite reliably for different alloy compositions.

The temperature of $1045{ }^{\circ} \mathrm{C}$ corresponded to the terminus of the carbon solubility in the V-MX + $\mathrm{Nb}-\mathrm{MX}$ phase field, as shown in Figure 6a. At this temperature range, a phase transformation reaction accompanied by the formation of the three types of Nb-bearing FCC precipitates: Nb-rich, V-rich and Ti-rich was obtained. Whether this could be considered as a transformation of the V-rich precipitates of the V-MX type (containing $\sim 47 \mathrm{wt} . \% \mathrm{~V}$ and $\sim 32 \%$ of $\mathrm{Nb}$ ) into a new FCC phase in which the amounts of $\mathrm{Nb}$ and $V$ are practically reversed, and the evolution of Ti-rich precipitate remains to be studied. Hong et al. [25] reported dendritic Nb-rich carbonitrides in high strength low alloy steel. On reheating the HSLA steel from 1050 to $1400{ }^{\circ} \mathrm{C}$, the $\mathrm{Nb}$ content decreased with increasing temperature till $1250{ }^{\circ} \mathrm{C}$. However, eventually, Ti started to dissolve into the austenite phase after $1300{ }^{\circ} \mathrm{C}$. A similar observation was made in Grade 91 steel where the $(\mathrm{Ti}, \mathrm{Nb})(\mathrm{N}, \mathrm{C})$ precipitate was stable at higher temperature compared to $(\mathrm{Nb}, \mathrm{V})(\mathrm{C}, \mathrm{N})$ and $(\mathrm{V}, \mathrm{Nb})(\mathrm{N}, \mathrm{C})$ precipitates. The solubility of $(\mathrm{V}, \mathrm{Nb})(\mathrm{C}, \mathrm{N})$ was higher than that of $(\mathrm{Ti}, \mathrm{Nb})(\mathrm{C}, \mathrm{N})$ and $(\mathrm{Nb}, \mathrm{Ti})(\mathrm{C}, \mathrm{N})$ in both ferrite and austenite phases [26].

\section{Conclusions}

The heat treatment study of Grade 91 steel was performed, and Thermo-Calc calculations were used to predict the stability of various phases and provide guidance for future research in this direction. The hardness of the alloy decreased with increasing normalizing and tempering temperatures and times. The decrease in hardness was attributed to increase in the grain size, martensite lath size, and decrease in dislocation density and precipitate coarsening. Differential scanning calorimetry indicated the various phase changes and precipitate reactions taking place during heating and cooling of Grade 91 steel. The Thermo-Calc predicted the evolution of ferrite and austenite phases, and various precipitates. With the help of differential scanning calorimetry study and Thermo-Calc, various temperatures important to heat treatment of Grade 91 steel were identified. Normalizing of Grade 91 steel should be carried out in the temperature range of $1040-1270{ }^{\circ} \mathrm{C}$, and tempering in the temperature range of $745-820^{\circ} \mathrm{C}$. Specific tempering optimization was not feasible in this study since only hardness was evaluated without any measurement of ductility and other relevant properties.

\section{Acknowledgments}

This research was performed using funding received from the DOE Office of Nuclear Energy's Nuclear Energy University Programs (NEUP) through the US Department of Energy Grant No. 42246 release 59. We would like to thank Zack Wuthrich and Tshering Sherpa for their assistance with the optical microscopy work. 


\section{Author Contributions}

Triratna Shrestha carried out experiments under Indrajit Charit and Gabriel P. Potirniche's guidance. Michael V. Glazoff performed the ThermoCalc calculations under Indrajit Charit and Triratna Shrestha's guidance. Data analyses were done in collaboration and characterization were done by Triratna Shrestha and Sultan F. Alsagabi.

\section{Conflicts of Interest}

The authors declare no conflict of interest.

\section{References}

1. Charit, I.; Murty, K.L. Structural materials issues for the next generation fission reactors. JOM 2010, 62, 67-74.

2. Murty, K.L.; Charit, I. Structural materials for Gen-IV nuclear reactors: Challenges and opportunities. J. Nucl. Mater. 2008, 383, 189-195.

3. Rojas, D. $9 \%-12 \%$ Cr Heat Resistant Steels: Alloy Design, Tem Characterization of Microstructure Evolution and Creep Response at $650^{\circ} \mathrm{C}$. Ph.D. Thesis, Ruhr-University Bochum, North Rhine-Westphalia, Germany, 2011.

4. Vishwanathan, R.; Bakker, W.T. Materials for boilers in ultra-supercritical power plants. In Proceedings of the 2000 International Joint Power Generation Conference, Miami Beach, FL, USA, 23-26 July 2000; pp. 1-22.

5. Buhre, B.J.P.; Gupta, R.; Richardson, S.; Sharma, A.; Spero, C.; Wall, T. PF-Fired supercritical boilers: Operational issues and coal quality impacts. Available online: http://www.steamforum. com/pictures/Supercritical\%20TN\%2020\%20PF\%20Super\%20Critical.pdf (accessed on 20 January 2015).

6. Shrestha, T.; Basirat, M.; Charit, I.; Potirniche, G.P.; Rink, K.K. Creep deformation mechanisms in modified 9Cr-1Mo steel. J. Nucl. Mater. 2012, 423, 110-119.

7. Basirat, M.; Shrestha, T.; Potirniche, G.P.; Charit, I.; Rink, K. A study of the creep behavior of modified 9Cr-1Mo steel using continuum damage modeling. Int. J. Plast. 2012, 37, 95-107.

8. Shrestha, T.; Basirat, M.; Charit, I.; Potirniche, G.P.; Rink, K.K. Creep rupture behavior of Grade 91 steel. Mater. Sci. Eng. A 2013, 565, 382-391.

9. Ahn, J.C.; Sim, G.M.; Lee, K.S. Effect of aging treatment on high temperature strength of $\mathrm{Nb}$ added ferritic stainless steels. Mater. Sci. Forum 2005, 475, 191-194.

10. Ganesh, B.J.; Raju, S.; Rai, A.K.; Mohandas, E.; Vijayalakshmi, M.; Rao, K.B.S.; Raj, B. Differential scanning calorimetry study of diffusional and martensitic transformations in some 9 wt-\% Cr low carbon ferritic steels. Mater. Sci. Technol. 2011, 27, 500-512.

11. Yoshino, M.; Mishima, Y.; Toda, Y.; Kushima, H.; Sawada, K.; Kimura, K. Influence of normalizing heat treatment on precipitation behavior in modified 9Cr-1Mo steel. Mater. High Temp. 2008, 25, 149-158.

12. Totemeier, T.C.; Tian, H.; Simpson, J.A. Effect of normalization temperature on the creep strength of modified 9Cr-1Mo steel. Metall. Mater. Trans. 2005, 37, 1519-1525. 
13. Dudko, V.; Delyakov, A.; Kaibyshev, R. Effect of tempering on mechanical properties and microstructure of a 9\% Cr heat resistant steel. Mater. Sci. Forum 2012, 706, 841-846.

14. Sawada, K.; Suzuki, K.; Kushima, H.; Tabuchi, M.; Kimura, K. Effect of tempering temperature on Z-phase formation and creep strength in $9 \mathrm{Cr}-1 \mathrm{Mo}-\mathrm{V}-\mathrm{Nb}-\mathrm{N}$ steel. Mater. Sci. Eng. A 2008, 480, 558-563.

15. Masuyama, F.; Nishimura, N. Experience with creep-strength enhanced ferritic steels and new emerging computational methods In Proceedings of the 2004 ASME/JSME Pressure Vessels and Piping Conference, San Diego, CA, USA, 25-29 July 2004; Volume 476, pp. 85-92.

16. Shen, Y.Z.; Kim, S.H.; Cho, H.D.; Han, C.H.; Ryu, W.S. Identification of precipitate phases in a $11 \mathrm{Cr}$ ferritic/martensitic steel using electron microdiffraction. J. Nucl. Mater. 2010, 400, 64-68.

17. Anderson, P.; Bellgard, T.; Jones, F.L. Creep deformation in a modified 9Cr-1Mo steel. Mater. Sci. Technol. 2003, 19, 207-213.

18. Das, C.R.; Albert, S.K.; Bhaduri, A.K.; Srinivasan, G.; Murty, B.S. Effect of prior microstructure and mechanical properties of modified 9Cr-1Mo steel weld joints. Mater. Sci. Eng. A 2008, 477, 185-192.

19. Silwal, B.; Li, L.; Deceuster, A.; Griffiths, B. Effect of post-weld heat treatment on toughness of heat-affected zone of Grade 91 steel. Welding J. 2013, 92, 80s-87s.

20. Shtansky, D.V.; Inden, G. Phase transformation in Fe-Mo-C and Fe-W-C steels-II. Eutectoid reaction of M23C6 carbide decomposition during austenitization. Acta Mater. 1997, 45, 2879-2895.

21. Ganesh, B.J.; Raju, S.; Mohandas, E.; Vijayalakshmi, M. Effect of thermal aging on the transformation temperatures and specific heat characteristics of $9 \mathrm{Cr}-1 \mathrm{Mo}$ ferritic steel. Defect Diffus. Forum 2008, 279, 85-90.

22. Oono, N.; Nitta, H.; Iijima, Y. Diffusion of $\mathrm{Nb}$ in $\alpha$-iron. Mater. Trans. 2003, 44, 2078-2083.

23. Raju, S.; Ganesh, B.J.; Rai, A.K.; Saroja, S.; Mohandas, E.; Vijayalakshmi, M.; Raj, B. Drop calorimetry studies on $9 \mathrm{Cr}-1 \mathrm{~W}-0.23 \mathrm{~V}-0.06 \mathrm{Ta}-0.09 \mathrm{C}$ reduced activation steel. Int. J. Thermophys. 2010, 31, 399-415.

24. Hald, J.; Korcakova, L.; Danielsen, H.K.; Dahl, K.V. Thermodynamics and kinetic modeling: Creep resistant materials. Mater. Sci. Technol. 2009, 24, 149-158.

25. Hong, S.G.; Jun, H.J.; Kang, K.B.; Park, C.G. Evolution of precipitates in the Nb-Ti-V microalloyed HSLA steels during reheating. Scr. Mater. 2003, 48, 1201-1206.

26. Taylor, K.A. Solubility products of titanium-, vanadium-, and niobium-carbide in ferrite. Scr. Mater. 1995, 32, 7-12.

(C) 2015 by the authors; licensee MDPI, Basel, Switzerland. This article is an open access article distributed under the terms and conditions of the Creative Commons Attribution license (http://creativecommons.org/licenses/by/4.0/). 